\title{
「知識·芸術·文化情報学研究会」を振り返る
}

\section{Study Group of Informatics on Knowledge, Art, and Culture}

\author{
村川猛彦 ${ }^{1 *}$ \\ Takehiko MURAKAWA ${ }^{1 *}$
}

1 和歌山大学

Wakayama University

干 640-8510 和歌山県和歌山市栄谷930

E-mail: takehiko@sys.wakayama-u.ac.jp

*連絡先著者 Corresponding Author

関西において，芸術・文化，およびその 他の関連する分野の情報・知識研究に興味 のある学生および若手研究者を主に意識 し, 発表・交流のための場を提供するため, 「知識・芸術・文化情報学研究会」を2011 年度に発足させ，2012年1月21日を第1回と し，年1回のペースで，本稿執筆時までに7 回の研究集会を開催してきた。筆者は世話 役の一人として, 初回より運営に携わって いる.

本学会の関西部会およびアート・ドキュ メンテーション学会関西地区部会が共催 していることから，この研究会では関西の 学生・若手研究者らの応募を勧奨しつつも, 発表者の年齢や研究年数, また所在につい て，制約を設けていない。開催年月日およ び発表内容 (発表者, 発表題目ならびに要 旨）は，回ごとにページを作成して，関西 部会ページ[1]よりリンクしている，開催日 および発表件数を表 1 に示す。最も西では 佐賀大学の方による発表があった。関東か
らの発表も少なくない。記録を見る限り， 北海道・東北からの発表はまだない.

表1 知識・芸術 - 文化情報学研究会開催状況

\begin{tabular}{|c|c|c|}
\hline & 開催日 & 発表件数 \\
\hline 第1回 & 2012年1月21日 & 13件 \\
\hline 第2回 & 2013年2月9日 & 7件 \\
\hline 第3回 & 2014年2月8日 & 10件 \\
\hline 第4回 & 2015年2月7日 & 13件 \\
\hline 第5回 & 2016年2月6日 & 6件 \\
\hline 第6回 & 2017年1月21日 & 7件 \\
\hline 第7回 & 2018年2月10日 & 8件 \\
\hline
\end{tabular}

注 : 第3回は特別セッションの講演 1 件および発 表2件を含む. 第4回は特別セッションの発表3 件を含む。

この研究会では「予稿集」を発行してい ない，運営側で，発表要旨などをまとめた プログラムを用意し配布するほかに，各発 表者にはレジュメを予定参加者分だけ作 成し，会場に持参してもらっている，筆者 
が関わった範囲で，発表者が資料を持ち寄 るスタイルの成果発表の場として，1990年 代に参加していた「暗号と情報セキュリテ イシンポジウム」が思い浮かぶ。 セキュリ ティへの関心そして聴講者は年々増加し, 個人的にそのシンポジウムに参加しなく なった回から，予稿集を発行する形式にな った，という話を，何年か前にこの研究会 の開催挨拶に使わせていただいたことが ある。

筆者の研究室とこの研究会の関わりにつ いて述べておきたい. 各回, 研究室の大学院 生1〜3名に発表してもらってきた。いずれも 博士前期課程（マスターコース）の学生であ り，2年連続して発表した者も5名いる.

和歌山大学大学院システム工学研究科に おいては, 例年, 2 月の上中旬に修士論文の提 出ののち発表会を実施している. この研究会 にM2学生が発表する場合には，修士論文と 同じ成果であることが多い，M1学生の発表 となると，修士研究の中間段階の報告となっ ている.

ところでこの研究会は単独発表でも連名 による発表でもよく, 申込時の氏名および所 属をそのまま開催案内やプログラムに掲載 している．筆者の指導する学生についてはこ れまで単独発表とさせているが, 資料準備や リハーサルなどは，共著の場合と同じように 時間をとって指導している.

内容は，デジタルアーカイブ，テキストデ ータベースおよび全文検索，Webサービスの
構築を中心に, 研究室での活動を踏まえつつ, 基本的には各学生の成果をそのまま報告し てもらっている。この研究会で厳しい意見を もらったのち，6ページの成果に取りまとめ て5月の年次大会で発表させ, 学生奨励賞を いただいたこともあった.

学内でも, 博士前期課程の学生が順番に研 究の進捗を報告してディスカッションをす る場がある。学生の発表頻度はおおむね半年 に1回であり, 発表内容に対して点数が付け られ，進度の思わしくない学生には教員間で （本人のいないところで）意見交換がなされ る。したがって大学 (卒業研究および修士研 究）においては, 学術成果よりも, 学生の「頑 張り」を重視することになる. それに対して この研究会では, 点数や順位を付けたりする ことはない，それでも，興味深い発表と，発 表の仕方にさらなる努力が必要な発表を知 ることができる，それはシステム構築や定量 評価といった, 問題解決における本人の努力 量よりもむしろ，手がけるテーマの魅力，も しくは解決すべき問題がどのようなもので あるかについて，発表開始の数分で，適切に 話せているかどうかにかかっているように 思われる。

\section{参考文献}

［1］情報知識学会・関西部会.

http://www.jsik.jp/?kansai（2018年10月31 日参照） 